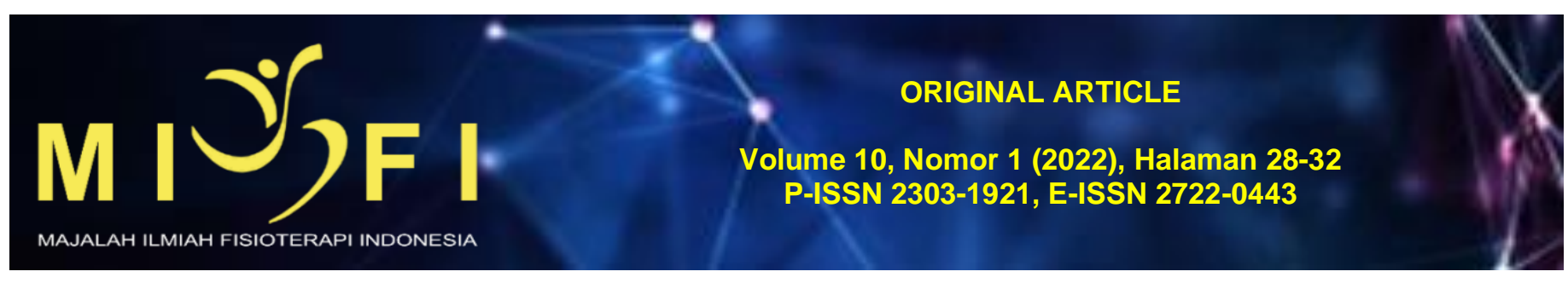

\title{
GAMBARAN RISIKO TERJADINYA PENYAKIT PARU OBSTRUKTIF KRONIS PADA PEMAIN BRASS INSTRUMENT MARCHING BAND SMA DI DENPASAR
}

\section{Made Andika Tresnanda Putra ${ }^{1 *}$, Ni Komang Ayu Juni Antari ${ }^{2}$, Sayu Aryantari Putri Thanaya ${ }^{3}$, Ida Ayu Dewi Wiryanthini ${ }^{4}$}

\author{
${ }^{1}$ Program Studi Sarjana Fisioterapi dan Profesi Fisioterapi, Fakultas Kedokteran Universitas Udayana, Denpasar, Bali \\ ${ }^{2,3}$ Departemen Fisioterapi, Fakultas Kedokteran Universitas Udayana, Denpasar, Bali \\ ${ }^{4}$ Departemen Biokimia, Fakultas Kedokteran Universitas Udayana, Denpasar, Bali \\ "Koresponden: katresnanda@gmail.com
}

Diajukan: 22 Juni 2021 | Diterima: 25 Juni 2021 | Diterbitkan: 25 Januari 2022

DOI: https://doi.org/10.24843/MIFI.2022.v10.i01.p06

\begin{abstract}
ABSTRAK
Pendahuluan: Pemain alat musik tiup merupakan orang-orang yang secara terus-menerus dalam periode waktu yang lama melakukan kegiatan yang berhubungan dengan pernapasan. Oleh karena itu, pemain alat musik tiup berisiko mengalami perubahan mekanisme pada paru yang bisa menyebabkan terkena penyakit paru obstruktif. Pemain alat musik tiup banyak ditemukan di dalam tim marching band. Di Indonesia skrining awal risiko terjadinya Penyakit Paru Obstruktif Kronis (PPOK) bagi pemain alat musik tiup masih sangat jarang dilakukan sehingga kondisi fisik dari masingmasing pemain masih kurang diketahui. Tujuan dari penelitian ini adalah untuk mengetahui gambaran risiko terjadinya PPOK pada pemain brass instrument marching band SMA di Denpasar.

Metode: Metode penelitian ini menggunakan metode penelitian deskriptif cross-sectional. Teknik pengambilan sampel pada penelitian ini menggunakan teknik total sampling dengan jumlah sampel sebanyak 50 orang. Skrining awal risiko terjadinya PPOK dilakukan dengan metode CAPTURE yang dapat mendeteksi secara dini adanya PPOK. Adapun faktor lain yang dicatat pada penelitian ini yaitu jenis kelamin, Indeks Massa Tubuh (IMT), dan kebiasaan merokok.

Hasil: Hasil penelitian menunjukkan bahwa gambaran risiko terjadinya PPOK pada pemain brass instrument marching band SMA di Denpasar yaitu $66 \%$ tidak berisiko, $28 \%$ berisiko sedang, dan $6 \%$ beresiko tinggi mengalami PPOK.

Simpulan: Responden dengan jenis kelamin laki-laki, IMT kategori kurus, dan yang memiliki kebiasaan merokok memiliki kecenderungan beresiko tinggi mengalami PPOK.
\end{abstract}

Kata Kunci: pemain alat musik tiup, PPOK, CAPTURE

\section{PENDAHULUAN}

Penyakit Paru Obstruktif Kronis (PPOK) adalah penyakit respirasi kronis yang terjadi karena adanya keterbatasan aliran udara yang sifatnya progresif. Biasanya berhubungan dengan adanya respon inflamasi kronis pada aliran napas yang meningkat dan disebabkan karena gas atau partikel berbahaya. ${ }^{1}$ Di dunia, rata-rata prevalensi Penyakit Paru Obstruktif Kronis (PPOK) adalah sebesar 3-11\%. Berdasarkan Riset Kesehatan Dasar (RISKESDAS) 2013, angka kejadian PPOK di Indonesia sebesar 3,7\%. Beberapa aktivitas yang dilakukan manusia dapat mempengaruhi PPOK salah satunya bermain alat musik tiup.

Bermain alat musik tiup menggambarkan aktivitas pernapasan pada sistem respirasi dan merupakan aktivitas pernapasan yang paling memberatkan walaupun bukan fungsi utama pernapasan. ${ }^{2}$ Pemain alat musik tiup banyak ditemukan di dalam tim marching band. Alat musik tiup pada marching band disebut brass instrument. Di Indonesia perkembangan marching band mengalami peningkatan yang begitu tinggi. Ini dibuktikan dengan adanya berbagai perlombaan marching band yang dilaksanakan di tingkat daerah hingga nasional. ${ }^{3}$

Pemain marching band biasanya melakukan latihan rutin seminggu sekali dengan durasi waktu tiga jam. Apabila mengikuti perlombaan latihan bisa dilakukan tiga kali seminggu bahkan sampai setiap hari. Terdapat penelitian yang menyatakan adanya hubungan negatif yang signifikan antara lama bermain alat musik tiup dan prediksi persentase Force Vital Capacity (FVC). Pemain alat musik tiup merupakan orang-orang yang secara terus-menerus dalam periode waktu yang lama melakukan kegiatan yang berhubungan dengan pernapasan. Para pemain yang rata-rata telah bermain alat musik tiup selama lebih dari 10 tahun dapat menyebabkan penurunan pada FVC yang juga dapat menyebabkan penyakit paru obstruktif. Menghirup napas dalam secara berulang dan peningkatan tekanan dapat merusak alveoli dan saluran udara kecil. ${ }^{4}$ Oleh karena itu, pemain alat musik tiup berisiko mengalami perubahan mekanisme pada paru yang bisa menyebabkan terkena penyakit paru-paru. ${ }^{5}$

Namun beberapa penulis menyatakan pemain alat musik tiup memiliki fungsi paru yang lebih baik karena latihan otot pernapasan secara berkelanjutan. Studi Sadgeo et al menunjukkan hasil nilai FVC yang lebih tinggi pada pemain alat musik tiup dibandingkan dengan bukan pemain alat musik tiup. Nilai FVC yang lebih tinggi pada pemain alat musik tiup dapat dibuktikan karena pola pernapasannya yang teratur dalam menggunakan seluruh kapasitas vital dengan terampil selama bermain dengan inspirasi dalam lalu diikuti dengan ekspirasi yang panjang melalui instrument .6,7 
Di Indonesia skrining awal risiko terjadinya penyakit paru obstruktif kronis bagi pemain alat musik tiup masih sangat jarang dilakukan sehingga kondisi fisik dari masing-masing pemain masih kurang diketahui. Jika skrining sudah dilakukan maka akan diketahui bagaimanakah efek bermain alat musik tiup terhadap kesehatan pemain brass instrument pada marching band, sehingga para pemain dapat melakukan upaya preventif sejak dini. Berdasarkan uraian diatas penulis melakukan penelitian untuk mengetahui gambaran risiko terjadinya penyakit paru obstruktif kronis pada pemain brass instrument marching band SMA di Denpasar.

\section{METODE}

Rancangan penelitian ini menggunakan rancangan deskriptif cross-sectional yang dilaksanakan pada bulan Maret-April 2021 di SMA di Denpasar yang memiliki ekstrakurikuler marching band. Teknik pengambilan sampel pada penelitian ini menggunakan teknik total sampling dengan jumlah sampel sebanyak 50 orang yang memenuhi kriteria inklusi dan eklusi. Adapun kriteria inklusi pada penelitian ini yakni anggota dari marching band di sekolahnya yang memainkan brass instrument sedangkan kriteria eklusinya yaitu memiliki riwayat penyakit paru seperti tuberculosis (TBC), pneumonia, bronkitis, dan asma.

Variabel dalam penelitian ini adalah penyakit paru obstruktif kronis. Risiko terjadinya PPOK ditentukan dengan kuisioner COPD Assessment in Primary Care to Identify Undiagnosed Respiratory Disease and Exacerbation Risk (CAPTURE). Metode CAPTURE terdiri dari lima pertanyaan yang mengevaluasi penyakit pernapasan, adanya paparan, rasa mudah lelah, dan gangguan napas. ${ }^{8}$ Subjek yang mendapatkan nilai 0-1 tergolong ke kategori tidak berisiko mengalami PPOK. Subjek yang mendapatkan nilai 2-4 tergolong ke kategori beresiko sedang mengalami PPOK. Subjek yang mendapatkan nilai 5-6 tergolong ke kategori berisiko tinggi mengalami PPOK. Penelitian ini juga meneliti faktorfaktor yang mempengaruhi risiko terjadinya PPOK yaitu jenis kelamin, Indeks Massa Tubuh (IMT), dan kebiasaan merokok.

Penelitian ini telah ditinjau dan lulus uji kelaikan etik dari Komisi Etik Penelitian (KEP) Fakultas Kedokteran Universitas Udayana/ Rumah Sakit Umum Pusat Sanglah Denpasar dengan nomor 1159/UN14.2.2.VII.14/LT/2021. Penelitian diawali dengan meminta izin dan koordinasi dengan masing-masing SMA untuk mengambil data penelitian. Pengambilan data ini dilakukan secara online akibat adanya pandemi COVID-19 yang dimulai dari penjelesan mengenai tujuan dan manfaat dari penelitian ini, kemudian pengisian informed consent, lalu dilanutkan dengan anamnesis data diri subjek dan pengisian kuisioner. Data yang telah didapat kemudian dianalis menggunakan IBM Statistical Package for The Social Sciences (SPSS) 25 secara deskriptif.

\section{HASIL}

Tabel 1. Karakteristik Sampel

\begin{tabular}{lcc}
\hline Karakteristik & Frekuensi $(\mathrm{n})$ & Persentase (\%) \\
\hline Jenis Kelamin & & \\
Laki-laki & 22 & 44 \\
Perempuan & 28 & 56 \\
IMT & & \\
Kurus & 9 & 18 \\
Normal & 33 & 66 \\
Gemuk & 8 & 16 \\
Kebiasaan Merokok & \\
Ya & 5 & 10 \\
Tidak & 45 & 90
\end{tabular}

Berdasarkan pada Tabel 1. diketahui frekuensi sampel laki-laki sebanyak 22 responden (44\%) dan sampel perempuan sebanyak 28 responden (56\%). Karakteristik sampel berdasarkan IMT adalah sebanyak 9 responden (18\%) kategori kurus, 33 responden (66\%) kategori normal, dan 8 responden (16\%) kategori gemuk. Pada kebiasaan merokok sebanyak 5 responden (10\%) memiliki kebiasaan merokok dan sebanyak 45 responden (90\%) tidak memiliki kebiasaan merokok.

Tabel 2. Gambaran Risiko Terjadinya PPOK Pada Pemain Brass Instrument

\begin{tabular}{ccc}
\hline Gambaran Risiko Terjadinya PPOK Pada Pemain Brass Instrument & Frekuensi (n) & Persentase (\%) \\
\hline Tidak Berisiko & 33 & 66 \\
Beresiko Sedang & 14 & 28 \\
Beresiko tinggi & 3 & 6 \\
\hline Total & 50 & 100 \\
\hline
\end{tabular}

Berdasarkan Tabel 2. didapatkan bahwa dari 50 responden, sebanyak 33 responden (66\%) tidak berisiko mengalami PPOK, sebanyak 14 responden (28\%) berisiko sedang mengalami PPOK, dan sebanyak 3 responden (6\%) beresiko tinggi mengalami PPOK. 
Tabel 3. Gambaran Risiko Terjadinya PPOK Pada Pemain Brass Instrument Berdasarkan Jenis Kelamin

\begin{tabular}{|c|c|c|c|}
\hline \multirow{2}{*}{ Gambaran Risiko Terjadinya PPOK Pada Pemain Brass Instrument } & \multicolumn{2}{|c|}{ Jenis Kelamin } & \multirow[t]{2}{*}{ Total } \\
\hline & Laki-laki & Perempuan & \\
\hline Tidak Beresiko & 18 & 15 & 33 \\
\hline Beresiko Sedang & 2 & 12 & 14 \\
\hline Beresiko Tinggi & 2 & 1 & 3 \\
\hline Total & 22 & 28 & 50 \\
\hline
\end{tabular}

Berdasarkan Tabel 3. diketahui bahwa dari 22 responden yang berjenis kelamin laki-laki, sebanyak 18 orang tidak beresiko dan diperoleh hasil yang sama yaitu masing masing 2 orang beresiko sedang dan beresiko tinggi mengalami PPOK. Pada sampel berjenis kelamin perempuan dari 28 responden sebanyak 15 orang tidak beresiko, 12 orang beresiko sedang, dan 1 orang beresiko tinggi mengalami PPOK.

Tabel 4. Gambaran Risiko Terjadinya PPOK Pada Pemain Brass Instrument Berdasarkan IMT

\begin{tabular}{ccccc}
\hline \multirow{2}{*}{ Gambaran Risiko Terjadinya PPOK Pada Pemain Brass Instrument } & \multicolumn{3}{c}{ IMT } & Total \\
\cline { 2 - 4 } & Kurus & Normal & Gemuk & \\
\hline Tidak Beresiko & 6 & 24 & 3 & 33 \\
Beresiko Sedang & 1 & 8 & 5 & 14 \\
Beresiko Tinggi & 2 & 1 & 0 & 3 \\
\hline Total & 9 & 33 & 8 & 50 \\
\hline
\end{tabular}

Berdasarkan Tabel 4. didapatkan informasi bahwa pada kategori IMT kurus sebanyak 6 orang tidak beresiko, 1 orang beresiko sedang, dan 2 orang beresiko tinggi mengalami PPOK. Kemudian pada kategori IMT normal sebanyak 24 orang tidak beresiko, 8 orang beresiko sedang, dan 1 orang beresiko tinggi mengalami PPOK. Sedangkan pada kategori IMT gemuk sebanyak 3 orang tidak beresiko dan 5 orang beresiko sedang mengalami PPOK.

Tabel 5. Gambaran Risiko Terjadinya PPOK Pada Pemain Brass Instrument Berdasarkan Kebiasaan Merokok

\begin{tabular}{cccc}
\hline \multirow{2}{*}{ Gambaran Risiko Terjadinya PPOK Pada Pemain Brass Instrument } & \multicolumn{3}{c}{ Kebiasaan Merokok } \\
\cline { 2 - 3 } Total & Tidak & Ya & \\
\hline Tidak Beresiko & 31 & 2 & 33 \\
Beresiko Sedang & 13 & 1 & 14 \\
Beresiko Tinggi & 1 & 2 & 3 \\
\hline Total & 45 & 5 & 50 \\
\hline
\end{tabular}

Berdasarkan Tabel 5. diketahui bahwa dari 45 responden yang tidak memiliki kebiasaan merokok sebanyak 31 orang tidak beresiko, 13 orang beresiko sedang dan 1 orang beresiko tinggi mengalami PPOK. Sedangkan dari 5 responden yang memiliki kebiasaan merokok sebanyak 2 orang tidak beresiko, 1 orang beresiko sedang, dan 2 orang beresiko tinggi mengalami PPOK.

\section{DISKUSI}

Hasil penelitian pada 50 responden menunjukkan jumlah responden perempuan lebih banyak dibandingkan laki-laki. Jumlah responden perempuan sebanyak 28 responden (56\%) sedangkan responden laki-laki sebanyak 22 responden (44\%). Kemudian berdasarkan IMT, responden terbanyak adalah pada IMT kategori normal sebanyak 33 responden (66\%) diikuti oleh IMT kategori kurus sebanyak 9 responden (18\%) dan IMT kategori gemuk sebanyak 8 responden (16\%). Selanjutnya berdasarkan kebiasaan merokok, lebih banyak responden yang tidak memiliki kebiasaan merokok yaitu sejumlah 45 responden (90\%) dibandingkan dengan yang memiliki kebiasaan merokok yaitu sebanyak 5 responden (10\%).

Pada penelitian ini, dari 50 responden sebanyak 33 responden (66\%) tidak berisiko mengalami PPOK. Hal tersebut cukup banyak dibandingkan dengan responden lainnya yaitu sejumlah 14 responden (28\%) berisiko sedang mengalami PPOK, dan 3 responden $(6 \%)$ beresiko tinggi mengalami PPOK. Sejalan dengan penelitian yang dilakukan oleh Dhule et al mengenai Pulmonary Function Test in Wind Instrument Players, pemain alat musik tiup memiliki fungsi paru yang lebih baik karena mereka melakukan latihan pernapasan untuk melawan high resistance pada instrumen terutama menggunakan otot ekspirasi mereka. Pelatihan kontrol napas pada pemain alat musik tiup diarahkan untuk meningkatkan fungsi otot pernafasan dan diafragma. Ini dicapai terutama dengan latihan yang dirancang untuk meningkatkan resistensi terhadap otot-otot pada inspirasi dalam dan menghasilkan ekspirasi lambat yang terkontrol dengan glotis yang terbuka. ${ }^{7}$

Penelitian ini meneliti faktor-faktor yang dapat mempengaruhi risiko terjadinya PPOK pada seseorang. Adapun faktor-faktor yang diteliti yaitu jenis kelamin, IMT, dan kebiasaan merokok. Gambaran risiko terjadinya PPOK berdasarkan jenis kelamin menunjukkan laki-laki memiliki kecenderungan beresiko tinggi mengalami PPOK dibandingkan perempuan. Perempuan lebih rentan untuk terkena penyakit paru dibanding laki-laki. Berdasarkan anatomi dan fisiologi, wanita memiliki paru-paru yang lebih kecil serta volume dan kapasitas vital paru $20-25 \%$ lebih kecil dibandingkan laki-laki. Rata-rata kapasitas vital paru pada laki-laki adalah 4,8 liter dan pada perempuan 3,1 liter. ${ }^{9}$ Namun terdapat tinjauan secara sistematis yang mengumpulkan bukti yang tersedia dan memperkirakan ringkasan prevalensi PPOK berdasarkan jenis kelamin secara global dan di beberapa wilayah di dunia yang menyebutkan bahwa sebesar 9,2\% pada laki-laki dan 6,2\% pada perempuan mengalami PPOK. ${ }^{10}$ Prevalensi yang lebih tinggi pada laki-laki dapat dikaitkan dengan fakta bahwa merokok merupakan faktor risiko umum bagi laki-laki dan lebih banyak laki-laki 
yang merokok daripada perempuan. ${ }^{11}$ Pada PPOK terjadi keterbatasan aliran udara karena saluran udara dan alveoli kehilangan kelenturan yang diakibatkan peningkatan tahanan jalan napas sehingga memerlukan waktu yang lama untuk pengosongan paru. Akibatnya tidak bisa mengeluarkan karbon dioksida dengan baik dan oksigen pun menjadi berkurang. ${ }^{12}$

Berdasarkan faktor IMT, terdapat tiga kategori yaitu kategori kurus, normal, dan gemuk. Pemberian kategori IMT pada masing-masing responden berdasarkan klasifikasi nasional yang ditetapkan oleh Kementrian Kesehatan Republik Indonesia. Gambaran risiko terjadinya PPOK berdasarkan IMT menunjukkan IMT kategori kurus memiliki kecenderungan beresiko tinggi mengalami PPOK. Terdapat data yang menunjukkan bahwa orang dengan IMT ekstrem (kurus, obesitas, obesitas tidak wajar) memiliki prevalensi asma dan/atau PPOK yang lebih tinggi dibandingkan orang dengan IMT kategori normal. ${ }^{13}$ Penyakit PPOK mengakibatkan beberapa efek salah satunya adalah penurunan berat badan. Ini terjadi karena terdapat ketidakseimbangan antara energi yang digunakan dan energi yang masuk ke dalam tubuh. Energi yang digunakan meningkat disebabkan oleh peningkatan usaha dalam bernapas. ${ }^{14}$ Beberapa penelitian menunjukkan bahwa sebagian besar orang dengan IMT yang rendah mengalami sesak napas yang parah. Hal ini dikaitkan dengan obstruksi aliran udara yang lebih parah seperti yang ditunjukkan oleh volume ekspirasi paksa yang rendah pada detik pertama (FEV1). ${ }^{15}$

Penelitian kali ini juga melihat gambaran risiko terjadinya PPOK pada pemain brass instrument antara responden yang memiliki kebiasaan merokok dan tidak memiliki kebiasaan merokok. Gambaran risiko terjadinya PPOK berdasarkan kebiasaan merokok menunjukkan responden yang memiliki kebiasaan merokok memiliki kecenderungan beresiko tinggi mengalami PPOK. Salah satu faktor resiko utama terjadinya PPOK adalah merokok. Seperti penelitian yang dilakukan oleh Terzhikan et al menunjukkan hal serupa, dimana pada perokok sebesar 17,8\% mengalami PPOK sedangkan pada orang yang tidak merokok yang mengalami PPOK sebesar 6,4\%. ${ }^{16}$ PPOK melibatkan kerusakan kantung udara pada paru-paru karena hilangnya elastisitas alveolus. Kerusakan tersebut juga menimbulkan perubahan struktur dan jaringan serta fungsi saluran pernapasan pada paru-paru yang disebabkan karena asap rokok. ${ }^{17}$ Pembesaran sel mukosa (hipertrofi) dan bertambahnya kelenjar mukus dapat terjadi di saluran napas besar. Penumpukan lendir, radang, hingga sel yang bertambah menyebabkan penyempitan terjadi pada saluran napas kecil. Oleh karena anatomi yang berubah di saluran napas maka timbulah perubahan fungsi paru pada perokok. Volume paru-paru menjadi lebih besar karena karbondioksida terperangkap didalamnya yang mana seharusnya dikeluarkan. Tubuh pun tidak mendapat oksigen yang mengakibatkan kesulitan bernapas dan terjadilah batuk kronis dan sesak napas. ${ }^{17}$

\section{SIMPULAN}

Berdasarkan hasil penelitian yang telah dilakukan, maka dapat disimpulkan gambaran risiko terjadinya PPOK pada pemain brass instrument marching band SMA di Denpasar yaitu $66 \%$ tidak berisiko, $28 \%$ berisiko sedang, dan $6 \%$ beresiko tinggi mengalami PPOK. Pemain brass instrument pada marching band SMA di Denpasar dengan jenis kelamin laki-laki, IMT kategori kurus, dan yang memiliki kebiasaan merokok memiliki kecenderungan beresiko tinggi mengalami PPOK. Bagi pemain brass instrument diharapkan supaya tetap melakukan latihan pernapasan secara teratur, makan makanan yang bergizi, serta menghindari kebiasaan merokok untuk menjaga fungsi paru yang lebih baik. Apabila peneliti lain ingin mengembangkan penelitian ini, diharapkan untuk menambahkan faktor yang diteliti yaitu terkait pengaruh lama bermain brass instrument terhadap fungsi paru serta dapat menggunakan pengukuran spirometri sebagai gold standard untuk mendapatkan nilai fungsi paru seseorang yang lebih spesifik.

\section{DAFTAR PUSTAKA}

1. Arto Yuwono Soeroto HS. Penyakit Paru Obstruktif Kronik (PPOK). Pedoman Diagnosis Penatalaksanaan Di Indones. 2014;2013:32.

2. Bouros E, Protogerou V, Castana O, Vasilopoulos G. Respiratory function in wind instrument players. Med del Lav. 2018;30(3):204.

3. Virgan H. Pelatihan Trumpet Di Marching Band Locomotive Pt Kai Bandung. Swara J Antol Dep Pendidik Seni Musik FPSD UPI. 2013;1(3).

4. Studer L, Schumann DM, Stalder-Siebeneichler A, Tamm M, Stolz D. Does trumpet playing affect lung function?A case-control study. PLoS One. 2019;14(5):1-9.

5. Brzęk A, Famuła A, Kowalczyk A, Plinta R. Efficiency of lung ventilation for people performing wind instruments. Med Pr. 2016;67(4):427-33.

6. Sagdeo MM, Khuje PD. Pulmonary Functions in Trained and Untrained Wind Instrument Blowers. People's J Sci Res. 2012;5(2):9-12.

7. Dhule SS, Sunita BN, Gawali SR. Pulmonary Function Tests in Wind Instrument Players. Int J Sci Res. 2013;2(5):384-6.

8. Umar TP, Sriwijaya U, Stevanny B, Sriwijaya U, Andrean A, Sriwijaya U. PUSTAKA Kronis dengan Metode Capture TM : Potensi. 2018;(December).

9. Oviera A, Jayanti S, Suroto. Faktor-faktor yang Berhubungan dengan Kapasitas Vital Paru pada Pekerja Industri. J Kesehat Masy. 2016;4(1):267-76.

10. Ntritsos G, Franek J, Belbasis L, Christou MA, Markozannes G, Altman P, et al. Gender-specific estimates of COPD prevalence: A systematic review and meta-analysis. Int J COPD. 2018;13:1507-14.

11. Jain NK, Thakkar MS, Jain N, Rohan KA, Sharma M. Chronic obstructive pulmonary disease: Does gender really matter. Lung India. 2011;28(4):258-62.

12. Ariani I, Masna K, Fachri M, Spesialis D, Pengajar S, Kedokteran F, et al. Manajemen Perioperatif Penyakit Paru Obstruktif Kronik ( PPOK ). 2014;41(8):595-600. 
13. Liu Y, Pleasants RA, Croft JB, Lugogo N, Ohar J, Heidari K, et al. Body mass index, respiratory conditions, asthma, and chronic obstructive pulmonary disease. Respir Med. 2015;109(7):851-9.

14. Soemarwoto RAS, Mustofa S, Sinaga F, Rusmini H, Morfi W, Febriani N, et al. Hubungan Penyakit Paru Obstruksi Kronik ( PPOK ) dengan Indeks Massa Tubuh ( IMT ) di Klinik Harum Melati Pringsewu Tahun 2016-2017. J Kedokt Unila. 2019;3(1):73-7.

15. Sabir C, Kumar MS. Association between Dyspnea, Forced Expiratory Volume in $1 \mathrm{~s}$, and Body Mass Index in Chronic Obstructive Pulmonary Disease. 2016;3(11):28-31.

16. Terzikhan N, Verhamme KMC, Hofman A, Stricker BH, Brusselle GG, Lahousse L. Prevalence and incidence of COPD in smokers and non-smokers: the Rotterdam Study. Eur J Epidemiol. 2016;31(8):785-92.

17. Oktaria D, Ningrum MS. Pengaruh Merokok dan Defisiensi Alfa-1 Antitripsin terhadap Progresivitas Penyakit Paru Obstruktif Kronis ( PPOK ) dan Emfisema. Majority. 2017;6(2):42-7. 